\title{
Effect of moisture and temperature on the extrudate properties of milkfish (Chanos chanos) feed
}

\author{
S. SYED RAFFIC ALI, K. AMBASANKAR, S. BALACHANDRAN AND K. RAMACHANDRAN \\ ICAR-Central Institute of Brackishwater Aquaculture, 75, Santhome High Road, Raja Annamalaipuram \\ Chennai - 600 028, Tamil Nadu, India \\ e-mail: ambasankar@ciba.res.in
}

\begin{abstract}
The present study evaluated the effect of varying levels of moisture and temperature on the extrudate properties of the milkfish (Chanos chanos) feed containing $31.49 \%$ protein and $4.71 \%$ lipid. Two trials were conducted in a pilot scale twin screw extruder using $3 \mathrm{~mm}$ die. In the first trial, the effect of temperature on extrudate properties was studied at five different temperatures viz., 80-90, 90-100, 100-110, 110-120 and 120-130 ${ }^{\circ} \mathrm{C}$. The results revealed that the temperature levels of $100-110,110-120$ and $120-130^{\circ} \mathrm{C}$ resulted in significantly $(\mathrm{p}<0.05)$ lower bulk density $(\mathrm{BD})$ of the extrudate than at $80-90$ and $90-100^{\circ} \mathrm{C}$. Significantly $(\mathrm{p}<0.05)$ lower water solubility index (WSI) was recorded at $100-110^{\circ} \mathrm{C}$, while further increase in temperature failed to show further reduction in water solubility. The pellet durability index (PDI) and expansion ratio (ER) showed a non-significant difference among the extrudates at $100-110,110-120$ and $120-130^{\circ} \mathrm{C}$. In the second trial, the effect of additional moisture on the extrudate was evaluated by including water at 20,25, 30 and $35 \%$ and the results revealed that $30 \%$ moisture addition resulted in significantly $(\mathrm{p}<0.05)$ lower BD, WSI and PDI of the extrudate than the other levels. The highest moisture level of $35 \%$ led to difficulty in operation while the lower levels from $25 \%$ failed to produce floating pellets. Results of this study infers that $30 \%$ moisture addition and a temperature of $100-110^{\circ} \mathrm{C}$ is optimal for production of water stable floating milk fish feeds.
\end{abstract}

Keywords: Extrusion, Feed characteristics, Milkfish, Moisture, Temperature

\section{Introduction}

Milkfish (Chanos chanos) is widely distributed throughout the tropical and subtropical Indo-Pacific oceans and can tolerate very wide ranges of environmental conditions (Franklin, 2006). This fish is a potential candidate species with good production potential for culture in fresh, brackish and marine water. It is considered as one of the cheapest source of animal protein. Among cultivable marine finfishes, milkfish is known to grow quickly in coastal ponds and can attain harvestable size in 6-12 months (Barman et al., 2012). Milkfish, in its natural habitat, apparently feeds on planktonic microorganisms and is most frequently designated as microphagous and planktivore (Sivakumar et al., 2013). In the brackishwater aquaculture sector, there will be most reliable growth market for prepared feeds. In this context it is to be noted that there are two major challenges for profitable fish feed production that includes feed formulation and processing (Riaz, 2009). Extrusion cooking is a high-temperature short-time process in which a final product is obtained by heating, mixing, shearing and forcing material through a die (Chevanan et al., 2009). Extrusion technology is commonly used to prepare fish feeds, since physical properties, such as water stability, durability, hardness, oil absorption capacity, nutrient digestibility and buoyancy control, usually are improved compared to steam pelleted diets (Sorensen et al., 2009). Extrusion eliminates microbial load, reduces the level of thermo labile antinutrients present in plant material and improves the digestibility of dietary components (Barrows et al., 2007). Extrusion processing and ingredient formulation are the two greatest factors that affect the quality of feeds. The extrudate property is determined by an array of operating parameters among which moisture and temperatures are the major physical factors that have direct effect on the quality of the extrudate. Extensive research has been conducted on the effect of moisture content on the extrudate properties for several starch and protein based feed materials (Shukula et al., 2005). Similarly temperature has got a significant role in the final product characteristics. Determining the effects of various moisture levels and extrusion temperature will help in preparation of quality extruded feeds. For most cultured fish species, the extruded pellets must remain intact in water for approximately $4 \mathrm{~h}$. Proper operation of processing equipment and selection of ingredients can extend this time. Hence, an attempt was made to study the effect of varying levels of temperature and moisture addition on the extrude property of standard milkfish feed developed at ICAR-Central Institute of Brackishwater 
Aquaculture (ICAR-CIBA), Chennai using a twin screw extruder (M/S. Jinan Saibainuo Technology, China).

\section{Materials and methods}

Preparation of experimental diets

The standard ICAR-CIBA developed milkfish feed (Milkfish Grow out ${ }^{\text {Plus }}$ ) was formulated to contain $31.49 \%$ protein with $4.71 \%$ lipid. The feed was prepared using locally available indigenous feed ingredients. The ingredient composition of the experimental diet is given in Table 1. Two trials were carried out in a pilot scale twin screw extruder using $3 \mathrm{~mm}$ die. The feed was processed using standard protocols followed at the feed mill of ICAR-CIBA, with variation in temperature in the first trial and moisture addition in the second trial. In the first trial, the extrusion was carried out at five different temperatures viz., 80-90, 90-100, 100-110, 110-120 and $120-130^{\circ} \mathrm{C}$ and the extrudate was dried to a moisture content of less than $11 \%$ and subjected for analysis. In the second trial, the effect of additional moisture at 20, 25, 30 and $35 \%$ levels on the extrudate property was studied. The required level of moisture content was adjusted by adding required quantity of potable water in the mixer. Trials were repeated thrice and the average values of the three trials were taken for analysis.

\section{Proximate composition of experimental diets}

The proximate composition of the experimental diets was analysed by following standard procedures of AOAC (2012). Moisture was calculated by gravimetric analysis by oven drying at $105^{\circ} \mathrm{C}$ for $12 \mathrm{~h}$. Crude protein (CP) was determined by Kjeldahl method ( $\mathrm{N}$ x 6.25) after acid hydrolysis (Kjeltec 2100, FOSS, Tecator, Sweden). Crude lipid (CL) was calculated gravimetrically after extraction with petroleum ether in a soxhlet system (SOCS, Pelican, India) after subjecting the extrudate for acid hydrolysis. Total ash was determined gravimetrically by igniting at $600^{\circ} \mathrm{C}$ for $6 \mathrm{~h}$ in muffle furnace. Crude fiber was estimated gravimetrically after acid and alkali digestion and loss in mass by combustion at $600^{\circ} \mathrm{C}$ for $3 \mathrm{~h}$. Nitrogen free extract (NFE) was calculated by difference.

\section{Measurement of extrudate properties}

\section{Bulk density}

Bulk density (BD) was measured using a standard bushel tester following the method prescribed by the USDA (1999).

\section{Water solubility index}

Water solubility index (WSI) was determined as the water-soluble fraction in the supernatant, expressed as percent of dry sample (Jones et al., 2000). The WSI was
Table 1. Ingredient composition (\%) of experimental diet

\begin{tabular}{lc}
\hline Ingredients $^{*}$ & $\%$ \\
\hline Fish meal $^{*}$ & 15 \\
Acetes & 5 \\
Dry fish & 3 \\
Soybean meal & 20 \\
Wheat & 12 \\
Rice & 12.5 \\
Maize & 8 \\
Groundnut oil cake & 4 \\
Rapeseed meal & 6 \\
Wheat bran & 5 \\
Rice bran & 6 \\
Fish oil & 1 \\
Lecithin & 0.5 \\
Vitamins and Minerals $^{*}$ & 2 \\
\hline
\end{tabular}

*Sardine fishmeal and fish oil, Bismifisheries, Mayiladuthurai, Tamil Nadu, India. \#Commercially sourced premix and each $\mathrm{kg}$ contains Vitamin A 2000000 IU, Vitamin D - 400000 IU, Vitamin E - 300 U, Vitamin K - 450 mg, Riboflavin - 800 mg, Pantothenic acid - 1 g, Nicotinamide - 4 g, Vitamin B12 - $2.4 \mathrm{mg}$, Choline chloride - $60 \mathrm{~g}, \mathrm{Ca}-300 \mathrm{~g}, \mathrm{Mg}-11 \mathrm{~g}, \mathrm{I}-400 \mathrm{mg}$, $\mathrm{Fe}-3 \mathrm{~g}, \mathrm{Zn}-6 \mathrm{~g}, \mathrm{Cu}-800 \mathrm{mg}$, Co - $180 \mathrm{mg}$.

determined from the amount of dried solids recovered by evaporating the resulting supernatant in an oven at $135^{\circ} \mathrm{C}$ for $2 \mathrm{~h}$. It was determined as the mass of solids in the extract to the original sample (\%).

\section{Pellet durability index}

Pellet durability index (PDI \%) was determined according to the method S269.4 (ASAE, 2004). Extrudates $(200 \mathrm{~g})$ were tumbled inside a pellet durability tester for 10 min and sieved. PDI was calculated as:

$$
\mathrm{PDI}=\frac{(\mathrm{Ma})}{(\mathrm{Mb})} \times 100
$$

where, $\mathrm{Ma}$ and $\mathrm{Mb}$ are mass $(\mathrm{g})$ of pellets retained on the screen after and before tumbling, respectively.

\section{Expansion ratio}

The expansion ratio (ER) was measured as per the method of Gujska and Khan (1990) dividing the diameter of the extrusion by the diameter of the socket opening in the extrusion exit.

\section{Pellet floatation test}

Floatation test was carried out using glass beakers. Twenty feed pellets of each diet were dropped into the beaker and observed for $60 \mathrm{~min}$ at $5 \mathrm{~min}$ interval. At the end of every observation, the number of pellets that are afloat were recorded. The mean numbers of the floating pellets were expressed as percentage of the initial number.

$\%$ pellet floats $=\frac{\text { Final number of floating pellets }}{\text { Initial number of floating pellets }} \times 100$ 


\section{Statistical analysis}

Data were analysed using one-way ANOVA to compare significant differences between treatments, whereas Duncan's multiple range tests was used to compare the means of the treatments. All the data were analysed using SPSS version 16.0 software.

\section{Results}

The results of the proximate composition of extruded diets (Table 2) showed that it contained 8.04, 31.49, 4.71, $4.29,12.7$ and $38.76 \%$ respectively of moisture, crude protein, crude lipid, crude fiber, total ash and nitrogen free extract (NFE). The results of the temperature optimisation trial (Table 3 ) revealed that the temperature settings of $100-110,110-120$ and $120-130^{\circ} \mathrm{C}$ resulted in significantly $(\mathrm{p}<0.05)$ lower BD than the temperature of $80-90$ and $90-100^{\circ} \mathrm{C}$ (Fig. 1). Similarly, the WSI also showed significantly $(\mathrm{p}<0.05)$ lower values at $100-110^{\circ} \mathrm{C}$ and further increase in temperature failed to show further reduction in water stability. The PDI and ER also showed a similar trend of non-significant difference among the extrudate obtained at $100-110,110-120$ and $120-130^{\circ} \mathrm{C}$. In the second trial, the effect of additional moisture at 20,25, 30 and $35 \%$ levels on the extrudate property (Table 4) revealed that $20 \%$ moisture addition failed to show important characteristics of extrusion as indicated by significantly $(\mathrm{p}<0.05)$ higher $\mathrm{BD}$ and water stability (Fig. 2). Feed mix containing 25\% moisture showed signs of extrusion resulting in good expansion of the finished product. This extrudate showed significantly $(p<0.05)$ lower BD and water stability than the extrudate obtained at $20 \%$ moisture. The lowest BD and water stability was obtained in the extrudate prepared with $30 \%$ moisture which was significantly $(p<0.05)$ better than the other two extrudates. Moisture addition of $35 \%$ led to difficulty in operation as the feed material got choked in the extruder barrel. As the level of moisture content increased, there was linear decrease in BD with increase in tendency for floating. Significant differences in colour were observed with increasing temperature and moisture. The extrusion temperatures of $120-130^{\circ} \mathrm{C}$ produced a darker brown colour that made the extrudates less appealing than the extrudates produced at lower temperatures. Results of this study infers that $30 \%$ moisture addition and a temperature

Table 2. Proximate composition (\%) of experimental diet

\begin{tabular}{ll}
\hline Proximate composition & $\%$ \\
\hline Moisture & 8.04 \\
Crude protein & 31.49 \\
Crude lipid & 4.71 \\
Crude fiber & 4.29 \\
Total ash & 12.71 \\
NFE & 38.76 \\
\hline
\end{tabular}

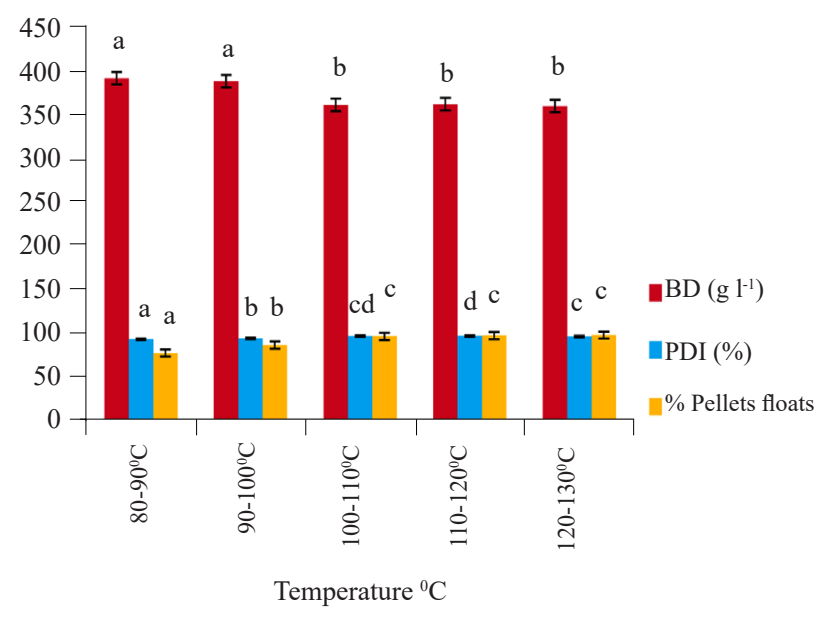

Fig. 1. Effect of varying levels of temperature on the bulk density (BD), pellet durability index (PDI) and \% pellets floats of milkfish feed

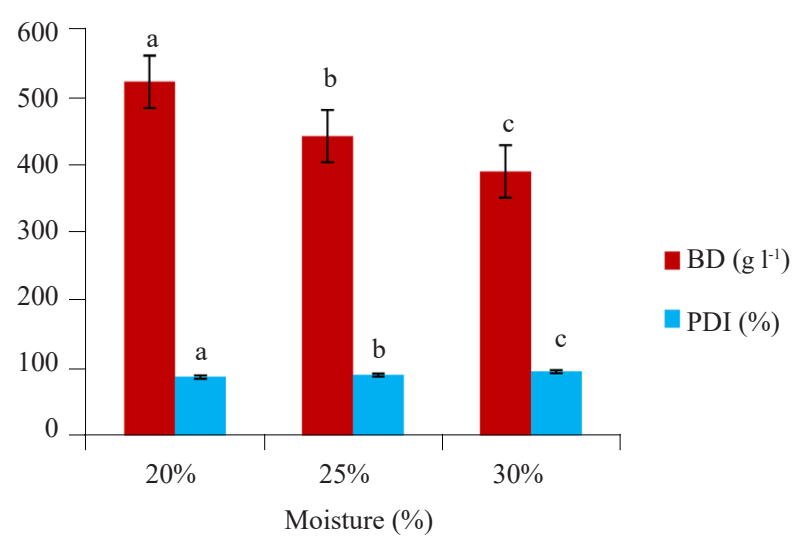

Fig. 2. Effect of varying levels of moisture on the bulk density (BD) and pellet durability index (PDI) of milkfish feed

of $100-110^{\circ} \mathrm{C}$ is optimal for production of water stable floating milkfish feeds.

\section{Discussion}

This forms the first attempt to investigate the effect of moisture and temperature on the extrudate properties of milkfish (C. chanos) feed. Results of the present study showed that there was a significant effect on BD, WSI, PDI and ER, when the feed mash was subjected to varying temperatures. It was found that $100-110^{\circ} \mathrm{C}$ is optimal to elicit the required extrudate properties while increasing the temperature beyond $100-110^{\circ} \mathrm{C}$ did not result in further reduction in $\mathrm{BD}$. Chevanan et al. (2007) reported that changing the temperature, moisture content and die dimensions were found to have significant effects on all the extrudate properties.

Bulk density is a key factor, as it influences storage space required at the processing plant, during shipping 
Table 3. Effect of varying temperature on the extrudate properties of milkfish feed

\begin{tabular}{llllll}
\hline Properties & $80-90^{\circ} \mathrm{C}$ & $90-100^{\circ} \mathrm{C}$ & $100-110^{\circ} \mathrm{C}$ & $110-120^{\circ} \mathrm{C}$ & $120-130^{\circ} \mathrm{C}$ \\
\hline BD $\left(\mathrm{g} \mathrm{l}^{-1}\right)$ & $389.36^{\mathrm{a}} \pm 4.62$ & $385.81^{\mathrm{a}} \pm 6.61$ & $358.83^{\mathrm{b}} \pm 3.38$ & $359.61^{\mathrm{b}} \pm 1.35$ & $357.61^{\mathrm{b}} \pm 1.95$ \\
Length $(\mathrm{mm})$ & $2.98 \pm 0.15$ & $3.04 \pm 0.14$ & $2.99 \pm 0.18$ & $2.82 \pm 0.26$ & $2.90 \pm 0.26$ \\
Diameter $(\mathrm{mm})$ & $3.39 \pm 0.09$ & $3.51 \pm 0.04$ & $3.63 \pm 0.10$ & $3.81 \pm 0.02$ & $3.84 \pm 0.03$ \\
WSI (\%) & $5.04^{\mathrm{a}} \pm 0.33$ & $4.25^{\mathrm{b}} \pm 0.06$ & $2.59^{\mathrm{c}} \pm 0.03$ & $2.43^{\mathrm{d}} \pm 0.03$ & $2.59^{\mathrm{c}} \pm 0.13$ \\
PDI (\%) & $91.83^{\mathrm{a}} \pm 0.49$ & $92.63^{\mathrm{b}} \pm 0.63$ & $95.46^{\mathrm{cd}} \pm 0.18$ & $95.59^{\mathrm{d}} \pm 0.40$ & $94.80^{\mathrm{c}} \pm 0.13$ \\
$\%$ Pellets floats & $76.12^{\mathrm{a}} \pm 9.28$ & $85.20^{\mathrm{b}} \pm 9.73$ & $95.1^{\mathrm{c}} \pm 4.33$ & $96.0^{\mathrm{c}} \pm 3.15$ & $96.60^{\mathrm{c}} \pm 3.02$ \\
ER & $1.13^{\mathrm{a}} \pm 0.02$ & $1.17^{\mathrm{ab}} \pm 0.02$ & $1.21^{\mathrm{b}} \pm 0.03$ & $1.27^{\mathrm{c}} \pm 0.04$ & $1.28^{\mathrm{c}} \pm 0.02$ \\
Colour & Brown & Brown & Brown & Dark brown & Dark brown \\
Odour & Fishy odour & Fishy odour & Fishy odour & Fishy odour & Fishy odour \\
Feed property & Floating & Floating & Floating & Floating & Floating
\end{tabular}

All values are means \pm SE of three observations

Means bearing different superscript in a row differ significantly $(p<0.05)$

Table 4. Effect of varying levels of moisture on the extrudate properties of milkfish feed

\begin{tabular}{llllc}
\hline Properties & $20 \%$ & $25 \%$ & $30 \%$ & $35 \%$ \\
\hline $\mathrm{BD}\left(\mathrm{g} \mathrm{l}^{-1}\right)$ & $522.0^{\mathrm{a}} \pm 11.14$ & $442.66^{\mathrm{b}} \pm 6.66$ & $390.33^{\mathrm{c}} \pm 9.50$ & Die choked \\
Length $(\mathrm{mm})$ & $2.71 \pm 0.08$ & $2.92 \pm 0.05$ & $2.93 \pm 0.04$ & - \\
Diameter $(\mathrm{mm})$ & $3.21 \pm 0.03$ & $3.48 \pm 0.02$ & $3.72 \pm 0.03$ & - \\
WSI $(\%)$ & $5.65^{\mathrm{a}} \pm 0.39$ & $2.56^{\mathrm{b}} \pm 0.41$ & $1.98^{\mathrm{c}} \pm 0.12$ & - \\
PDI (\%) & $88.59^{\mathrm{a}} \pm 0.62$ & $91.26^{\mathrm{b}} \pm 0.73$ & $96.28^{\mathrm{c}} \pm 0.61$ & - \\
$\%$ Pellets floats & 0 & 0 & $91.69 \pm 0.22$ & - \\
ER & $1.07^{\mathrm{a}} \pm 0.01$ & $1.16^{\mathrm{b}} \pm 0.02$ & $1.24^{\mathrm{c}} \pm 0.03$ & - \\
Colour & Brown & Brown & Brown & - \\
Odour & Fishy odour & Fishy odour & Fishy odour & - \\
Feed property & Sinking & Sinking & Floating & \\
\hline
\end{tabular}

All values are means \pm SE $(n=3)$

Means bearing different superscripts in a row differ significantly $(\mathrm{p}<0.05)$

and at animal production facilities. BD depends on the size, shape and the extent of expansion during extrusion. Increasing temperature had a significant effect on the BD (Chevanan et al., 2007). PDI essentially refers to quality of the diet as it is a measure of the physical integrity of finished feed pellets during handling and transport, with a goal of minimal generation of fines and broken pellets (Doizer, 2001). Temperature level of $100-110^{\circ} \mathrm{C}$ and above resulted in significantly $(\mathrm{p}<0.01)$ higher PDI than at lower temperature and this indicates that durable extruded pellets are produced at higher temperatures and a minimum of $100-110^{\circ} \mathrm{C}$ is optimal for preparation of milkfish extruded pellets with better PDI. It is very much relevant under practical condition that durable pellets alleviate the problem of dust formation. The main effects on PDI due to different processing conditions was attributed to temperature and moisture (Doizer, 2001). ER is also one of the significant parameters to be studied in the extrudate and it was found that the trend is similar to that of PDI indicating that better ER is obtained at $100-110^{\circ} \mathrm{C}$ and above. At this temperature, the starch present in the feed mix is sufficiently gelatinised and the resultant extrudate is having the required physical characteristics. ER is related to the apparent density and the sinking velocity of the extrudate (Conway and Anderson, 1973). The ER of extrudates decreased with increase in moisture content and was found to be highest at $150^{\circ} \mathrm{C}$ (Singh et al., 2007). Gujska and Khan (1990) reported that as the temperature of extrusion cooking increased, starchy material got completely cooked and consequently showed improved expansion. However, temperature showed a significant effect on the expansion index in diets with $93 \mathrm{~g} \mathrm{~kg}^{-1}$ bean flour in the temperature interaction and screw velocity. The results of the effect of varying temperature on the milkfish extrudate signifies that the temperature of $100-110^{\circ} \mathrm{C}$ is optimal for extrusion of milkfish feed.

Effect of varying levels of moisture addition on milkfish feed indicates that as the moisture level increased the bulk density decreased. However, when the moisture content was increased to $35 \%$, considerable difficulty was experienced in operating the extruder and the die was frequently getting choked indicating that higher moisture content at $35 \%$ is not ideal for production of extruded milkfish feed using twin screw extruder. Gonzalez et al. 
(2000) reported that moisture level and feed rate have significant effect on the expansion ratio of extrudates. Increase in feed rate results in higher expansion and higher level of moisture reduced the expansion of extrudates. It was observed that by increasing moisture level up to $18 \%$ resulted in a decrease in expansion ratio for corn starch. Similar kind of observation was also reported by Owusuansah et al. (1984). Rodriguez-Miranda et al. (2014) reported that the moisture content, in its lineal term significantly had effect on the expansion index of all the diets. On the contrary, increased expansion ratio and better extrusion was observed in our trial when moisture was increased from 20 to $30 \%$. Further, 30\% moisture addition resulted in significantly lower BD, WSI and PDI of the extrudate than the other levels. Chevanan et al. (2009) reported that changing the moisture content of the ingredient blends had a significant effect on the extrusion processing parameters as well, except for die temperature.

Water satiability index of extrudates increased with decrease in feed moisture and increase in temperature. In general, addition of pea grit reduced the WSI of extrudates (Singhet al., 2007). Water stability is another measurement for quality of fish feed and is defined as the amount of time a pellet requires before breaking up after it has been placed in water. Water stability quantifies the dissolving period and loss of nutrients once they are exposed to water. Generally, long time for water stability demonstrates high physical stability of extrudates. Besides, the time fish need to consume their rations is decisive for the duration of feed stability in water. In terms of product colour, visual judgment of the products point to ongoing lightening with rising temperature but to definite level. In this study the preferred brown product colour, which also indicates sufficient cooking, was achieved at $100-110^{\circ} \mathrm{C}$. Conversely the extrusion temperature of $120-130^{\circ} \mathrm{C}$ produced a darker colour that made the extrudates less suitable than the lower temperature.

Analysis of the extrudate characteristics revealed that milkfish feed containing $31.49 \%$ protein and $4.71 \%$ lipid requires a temperature setting of $100-110^{\circ} \mathrm{C}$ and $30 \%$ moisture addition for desired floating with better pellet characteristics and water stability. From this trial it may be deduced that the above operating parameters are optimal for production of floating extruded feeds for milkfish. However, further studies are required to know the feed acceptability and digestibility of the extrudates prepared at varying operating parameters.

\section{Acknowledgements}

The authors are grateful to the ICAR, New Delhi for funding the project on Outreach activity on Fish feeds. Authors express their sincere thanks to Dr. A. G. Ponniah, Former Director and Dr. K. K. Vijayan, Director,
ICAR-CIBA for providing necessary facilities for carrying out this work.

\section{References}

AOAC 2012. Official methods of analysis of the Association of Official Analytical Chemists, $19^{\text {th }}$ edn. Association of Official Analytical Chemists, Arlington, Virgina, USA.

ASAE 2004. American Society of Agricultural EngineersStandards, Engineering Practices and Data. ASAE: St. Joseph, Ml, USA.

Barman, U. K., Garg, S. K. and Bhatnagar, A. 2012. Effect of different salinity and ration levels on growth performance and nutritive physiology of milkfish, Chanos chanos. J. Fish. Aquac., 53: 1-11. https://doi.org/10.1111/j.14390426.2006.00698.x.

Barrows, F. T., Stone, D. A. J. and Hardy, R. W. 2007. The effects of extrusion conditions on the nutritional value of soybean meal for rainbow trout (Oncorhynchus mykiss). Aquaculture, 265: 244 -252.

Chevanan, N., Muthukumarappan, K. and Rosentrater, K. A. 2009. Extrusion studies of aquaculture feed using distillers dried grains with solubles and whey. Food Bioprocess Technol., 2: 177-185. DOI: 10.1007/s11947-007-0036-8.

Chevanan, N., Muthukumarappan, K., Rosentrater, K. A. and Julson, J. L. 2007. Effect of die dimensions on extrusion processing parameters and properties of DDGS-based aquaculture feeds. Cereal Chem., 84(4): 389-398.

Conway, H. F. and Anderson, R. A. 1973. Protein fortified extruded food products. Cereal Science Today, 18: 94.

Doizer, W. A. 2001. Cost-effective pellet quality for meat birds. Feed Manag., 52(2): 21-24.

Franklin Martinez, S., Mei-Chen, T. and Sin-Ping, Y. 2006. Milkfish (Chanos chanos) culture situations and trends. J. Fish. Soc. Taiwan, 33(3): 229 -244.

Gonzalez, R. J., Torres, R. L. and Anlon, M. C. 2000. Comparison of rice and corn cooking characteristics before and after extrusion. J. Food Nutr. Sci., 51(1): 29-34.

Gujska, E. and Khan, K. 1990. Effect of temperature on properties of extrudates from high starch fractions of navy, pinto and garbanzo beans. J. Food Sci., 55: 466-469. https://doi. $\operatorname{org} / 10.1111 / \mathrm{j} .1365-2621.1990 . t b 06788 . x$.

Jones, I., Chinnaswamy, R., Tan, Y. and Hanna, M. A. 2000. Physiochemical properties of ready-to-eat breakfast cereals. Cereal Foods World, 45: 164-168.

Owusuansnah, J., Van, D. V. and Stanley, D. W. 1984. Textural and microstructure changes in corn starch as a function of extrusion variables. J. Can. Inst. Food Sci. Technol., 17(1): $65-70$.

Riaz, M. N. 2009. Using extrusion to make floating and sinking fish feed: Controlling the water stability of feed. Feed Manag., 48(1): 21-24. 
Rodriguez-Miranda, J., Gomez-Aldapa, C. A., Castro-Rosas, J., Ramirez-Wong, B., Vivar-Vera, M. A., Morales-Rosas, I., Medrano-Roldan, H. and Delgado, E. 2014. Effect of extrusion temperature, moisture content and screw speed on the functional properties of aquaculture balanced feed. Emir. J. Food Agric., 26(8): 659-671.

Shukla, C. Y., Muthukumarappan, K. and Julson, J. L. 2005. Effect of single screw extruder die temperature, amount of distillers dried grains with solubles (DDGS) and initial moisture content on extrudates. Cereal Chem., 82(1):34-37. DOI: $10.1094 / C C-82-0034$.

Singh, B., Sekhon, K. S. and Singh, N. 2007. Effects of moisture, temperature and level of pea grits on extrusion behaviour and product characteristics of rice. Food Chem., 100: 198-202. DOI: 10.1016/j.foodchem.2005.09.042.

Sivakumar, R., Jayaprakash, M. and Munnusamy, N. 2013. Impact of heavy metals on antioxidant activity in different tissue of milkfish (Chanos chanos). Int. J. Appl. Biochem. Pharmacol. Tech., 4(1): 272-279.

Sorensen, M., Stjepanovic, N., Romarheima, O. H., Krekling, T. and Storebakken, T. 2009. Soybean meal improves the physical quality of extruded fish feed. Anim. Feed Sci. Tech., 149: 149 -161. DOI : 10.1016/j.anifeedsci.2008.05.010.

USDA 1999. Practical procedures for grain handlers: Inspecting grain. United States Department of Agriculture-Grain Inspection, Packers and Stockyards Administration. http:// 151.121.3.1 17/puhs/primer.pdf. 